\title{
MEASUREMENTS OF BLOOD FLOW AND BLOOD PRESSURE IN CLUBBED FINGERS
}

\author{
By MILTON MENDLOWITZ
}

(From the Medical Services of The Mount Sinai Hospital, New York)

(Received for publication July 26, 1940)

Studies on the peripheral circulation in patients with clubbed fingers were reported in a previous communication (1). The maximum heat elimination from the finger tip was found to be increased and the digital arterial pressure elevated above normal in various pulmonary conditions and in one case of congenital heart disease with cyanosis. In several cases of unilateral clubbing the results varied, and in two cases of hereditary clubbing normal brachial-digital arterial pressure gradients were found.

It is the purpose of this communication to report changes in method which have made possible the measurement of finger tip blood flow in cc. per minute and to present further observations on a series of patients with normal and on a series with clubbed fingers. Twelve normal subjects, one patient with essential hypertension, one with aplastic anemia, one with hyperthyroidism, two with acromegaly, two with rheumatoid arthritis, two with chronic pyelonephritis, one with renal and genital tuberculosis and one with chronic salpingitis were studied in the first series. The second series included two cases of hereditary clubbing, seventeen cases of various pulmonary diseases, two of congenital heart disease with cyanosis, seven of subacute bacterial endocarditis, three of ulcerative colitis, one of bacillary dysentery, one of regional ileitis and two of sprue, all with clubbed fingers. In three of the pulmonary cases, there was hypertrophic osteoarthropathy. One case of lung abscess was studied both before and after operation.

\section{DISCUSSION OF METHOD}

Stewart's method (2) for measuring hand blood flow was based on the principle that the amount of heat eliminated by the hand per minute in a water calorimeter is proportional to the volume flow of blood. Since the specific heat of the blood is approximately 1.0 , he concluded that each cc. of blood flowing through the hand would re- lease one calorie of heat to the calorimeter, provided that the temperature of the venous blood were $1^{\circ} \mathrm{C}$. less than that of the arterial blood. If, therefore, the temperature of the venous blood were $\mathrm{n}^{\circ} \mathrm{C}$. lower than that of the arterial, each cc. of blood would release $\mathrm{n}$ calories to the calorimeter. The number of cc. of blood flowing through the hand per minute could therefore be determined from the number of calories eliminated per minute, divided by the difference in temperature between arterial and venous blood. Since the hand, in a water calorimeter set several degrees below mouth temperature, was cooled approximately to the temperature of the calorimeter, Stewart assumed the temperature of the venous blood to be equivalent to the average calorimeter temperature. He also found mouth temperature to be equivalent to the temperature of the arterial blood and thus presented a formula whereby the blood flow through the hand could be determined.

It was found, however, by Harris and Marvin (3) that the actual temperature of the venous blood from the wrist, with the hand in the calorimeter, was from $1.4^{\circ}$ to $4.0^{\circ} \mathrm{C}$. higher than that of the calorimeter after five minutes' immersion and from $1.1^{\circ}$ to $2.7^{\circ} \mathrm{C}$. higher after fifteen minutes. This invalidated the formula.

Pickering (4) nevertheless considered the correspondence between heat elimination in calories per minute and blood flow sufficiently close to attempt to establish normal values with a standardized procedure consisting of warming the body before each observation. This was known to release sympathetic tone almost completely and thus eliminated fluctuations in blood flow caused by variations in blood vessel caliber.

In order to study clubbed fingers, the Stewart method as modified by Pickering was adapted to the finger tip (1). A very much narrower normal range of variation in heat elimination per unit of tissue, after release of sympathetic tone, was found for the finger tip than had been noted by Pickering for the hand. 
It was therefore thought that Stewart's formula, as presented below in METHOD, might have been found invalid for the hand because of a considerable indeterminate proportion of blood flow from the deep tissues. It might, however, be applicable to the finger tip where nearly all the blood flows through the surface capillaries and arteriovenous anastomoses. To test this, the temperature of the digital venous blood was measured in four subjects, as follows:

Sympathetic tone was released by immersing the left arm in water at a temperature of from $43^{\circ}$ to $45^{\circ} \mathrm{C}$. until sweating began. The entire fourth finger of the right hand was then immersed in an open calorimeter cup filled with water at an initial temperature of slightly less than $31^{\circ} \mathrm{C}$. After two to five minutes of stirring, a hypodermic needle thermocouple was inserted into a vein on the dorsum of the base of the finger. The temperature of the venous blood was recorded at the same time as that of the calorimeter.

TABLE I

Simultaneous temperatures of calorimeter and digital venous blood after release of sympathetic tone in four subjects

\begin{tabular}{c|c|c}
\hline \hline & Temperature of venous blood & Temperature of calorimeter \\
\cline { 2 - 3 } 1 & degrees centigrade & degrees centigrade \\
2 & 31.8 & 30.9 \\
3 & 31.8 & 31.0 \\
4 & 31.5 & 31.0 \\
& 31.6 & 31.4 \\
\hline
\end{tabular}

The results are presented in Table I. The temperature of the venous blood was from $0.2^{\circ}$ to $0.9^{\circ} \mathrm{C}$. (average $0.6^{\circ}$ ) higher than that of the calorimeter. The temperature of the arterial blood (mouth temperature ${ }^{1}$ ) was approximately $6.0^{\circ} \mathrm{C}$. higher than that of the calorimeter. It is probable, therefore, that about 90 per cent of the blood flowing through the entire finger was cooled to the temperature of the calorimeter, the remaining 10 per cent coming from the deep tissues. It should be noted that this proportion applies to the entire finger. In the terminal phalanx, there is a greater proportion of surface to volume and a proportionately greater number of arteriovenous anastomoses than in the entire finger. If, therefore, it were possible to measure venous blood

1 The close correspondence found by Stewart (2) between mouth temperature and the temperature of the arterial blood measured indirectly was confirmed by direct thermocouple measurement of arterial blood temperatures. temperature in the terminal phalanx, it would undoubtedly indicate that nearly 100 per cent of the blood flowing through the finger tip was cooled to the temperature of the calorimeter. These observations demonstrate the accuracy of Stewart's formula when used for the measurement of blood flow in the finger tip.

The normal range of variation in finger tip volume flow was between 0.21 and 0.29 cc. per sq. $\mathrm{cm}$. of finger tip surface per minute and between 0.57 and $0.97 \mathrm{cc}$. per cc. of finger tip per minute. The latter is in accord with the range found by Wilkins, Doupe and Newman (5) (0.6 to $1.2 \mathrm{cc}$ per cc. per minute). Their measurements were made with the finger plethysmograph on the terminal two phalanges after release of sympathetic tone by warming the body. For the purposes of this investigation the calorimetric method was preferable to the plethysmographic for several reasons. The apparatus of the former is simpler and can be used at the bedside. The small degree of distensibility of the vascular bed of the finger tip, moreover, makes it difficult to measure blood flow by the plethysmographic method in the terminal two phalanges and almost impossible in the terminal phalanx. It should be noted also that the range of variation per unit surface was considerably narrower than per unit volume. This was due, in part at least, to inaccuracy in the measurement of finger tip volume by water displacement.

The measurement of pressure gradients presented comparatively fewer problems. The brachial arterial blood pressure was measured by the standard auscultatory method and the digital arterial blood pressure with the Gaertner capsule (6), as already described (1). When sympathetic tone had been released it was usually possible to check these pressures within a few $\mathrm{mm}$. $\mathrm{Hg}$. Variations in systolic and diastolic pressures, when both were measured, made it impossible to determine representative brachial-digital gradients. These gradients could be standardized physiologically only if it were clinically feasible to determine true mean pressures. An approximation, however, to the physiological mean pressure gradient was adduced from the arithmetic mean pressures. The normal range of variation in arithmetic mean pressure gradient after release of sympathetic tone was from 9 to $40 \mathrm{~mm}$. $\mathrm{Hg}$. 


\section{METHOD}

Each observation was carried out as follows: With the subject sitting comfortably in bed in a room kept at a fairly constant temperature with minimal air currents, preliminary mouth temperature, pulse rate, and brachial and digital arterial blood pressures were recorded. The left arm was then immersed in a water bath which was continually stirred and the temperature of which was maintained between $43^{\circ}$ and $45^{\circ} \mathrm{C}$. After ten to twenty minutes, when release of sympathetic tone was almost complete, as indicated by the onset of generalized sweating, the fourth finger tip of the right hand was inserted into the water calorimeter set at approximately $6.5^{\circ} \mathrm{C}$. below mouth temperature. The calorimeter was stirred and the rise in temperature per minute recorded for several minutes until the total rise was about $1^{\circ} \mathrm{C}$. The finger tip was removed from the central opening of the calorimeter and a small cork inserted. The fall in calorimeter temperature was recorded for several minutes. Mouth temperature, pulse rate, and brachial and digital arterial blood pressures were again measured, following which the left arm was removed from the water bath. The surface area and the volume of the previously immersed finger tip were measured by strips of adhesive tape and water displacement, respectively.

Blood flow per unit surface of finger tip was calculated from the following formula:

$$
F=\frac{\left(\Delta t_{1}+\Delta t_{2}\right)(m+e)}{s a\left(t_{3}-t_{4}\right)},
$$

in which $F$ is the blood flow in cc. per sq.cm. per minute; $\Delta t_{1}$, the rise in temperature of the calorimeter per minute; $\Delta t_{2}$, the fall in temperature of the calorimeter per minute after removal of the finger tip; $m$, the volume of water in the cup; $e$, the hydrothermic equivalent of the cup, stirring device and thermometer bulb; $s$, the specific heat of the blood (approximately 1.0 ); $a$, the area of the immersed finger tip in sq.cms.; $t_{3}$, the temperature of the arterial blood (mouth temperature); and $t_{4}$, the temperature of the venous blood (average calorimeter temperature). To calculate the blood flow per unit volume, the volume of the finger tip in cc., $v$, is substituted for $a$ in the formula.

\section{RESULTS}

The results are presented in Tables IIA and IIB. In the cases of hyperthyroidism, aplastic anemia, essential hypertension and acromegaly, the blood flows and brachial-digital arterial pressure gradients were within normal limits. In the cases of chronic infection without clubbing, such as rheumatoid arthritis, pyelonephritis, renal tuberculosis, and salpingitis, the blood flows and brachial-digital arterial pressure gradients were also within the normal range.
TABLE II A

Normal fingers

\begin{tabular}{|c|c|c|c|c|c|}
\hline Diagnosis & $\begin{array}{l}\text { Blood } \\
\text { flow }\end{array}$ & $\begin{array}{l}\text { Blood } \\
\text { flow }\end{array}$ & $\begin{array}{l}\text { Brachial } \\
\text { arterial } \\
\text { pressure }\end{array}$ & $\begin{array}{c}\text { Digital } \\
\text { arterial } \\
\text { pressure }\end{array}$ & $\begin{array}{c}\text { Arith- } \\
\text { metic } \\
\text { mean } \\
\text { gradi- } \\
\text { ent }\end{array}$ \\
\hline & $\begin{array}{c}c c . \\
\text { per } \\
\text { sq. cm. } \\
\text { per } \\
\text { minute }\end{array}$ & $\begin{array}{c}c c . \\
\text { per } \\
c c . \\
\text { per } \\
\text { minute }\end{array}$ & $m m . H g$ & $m m . H_{g}$ & $\operatorname{mim}_{\mathrm{Hg}}$ \\
\hline Normal. & 0.25 & 0.69 & $128 / 80$ & $120 / 70$ & 9 \\
\hline Normal. & 0.24 & 0.59 & $102 / 74$ & $88 / 40$ & 24 \\
\hline Normal. & 0.22 & 0.62 & $125 / 84$ & $96 / 52$ & 30 \\
\hline Normal. & 0.28 & 0.93 & $135 / 94$ & $110 / 76$ & 22 \\
\hline Normal. & 0.23 & 0.62 & $114 / 82$ & $106 / 52$ & 19 \\
\hline Normal. . & 0.28 & 0.76 & $132 / 86$ & $116 / 60$ & 21 \\
\hline $\begin{array}{l}\text { Normal......... } \\
\text { Normal...... }\end{array}$ & $\begin{array}{l}0.27 \\
0.28\end{array}$ & $\begin{array}{l}0.72 \\
0.97\end{array}$ & $\begin{array}{l}112 / 82 \\
128 / 80\end{array}$ & $\begin{array}{r}84 / 70 \\
102 / 60\end{array}$ & $\begin{array}{l}20 \\
23\end{array}$ \\
\hline Normal. & 0.23 & 0.57 & $118 / 85$ & $102 / 64$ & 18 \\
\hline Normal. & 0.29 & 0.80 & $118 / 90$ & $96 / 60$ & 26 \\
\hline Normal. & 0.26 & 0.74 & $116 / 86$ & $98 / 54$ & 25 \\
\hline Normal. & 0.21 & 0.65 & $124 / 90$ & $100 / 35$ & 40 \\
\hline Aplastic anemia . & 0.20 & 0.60 & $112 / 70$ & $96 / 64$ & 11 \\
\hline Hyperthyroidism . . . & 0.22 & 0.73 & $130 / 78$ & $100 / 84$ & 12 \\
\hline Hypertension....... & 0.20 & 0.66 & $238 / 125$ & $216 / 130$ & 9 \\
\hline Acromegaly. & 0.22 & 0.54 & $108 / 86$ & $104 / ?$ & 12 \\
\hline $\begin{array}{l}\text { Acromegaly ....... } \\
\text { Rheumatoid arthritis }\end{array}$ & $\begin{array}{l}0.21 \\
0.28\end{array}$ & $\begin{array}{l}0.48 \\
0.88\end{array}$ & $\begin{array}{l}120 / 78 \\
120 / 80\end{array}$ & $\begin{array}{l}108 / 04 \\
100 / 76\end{array}$ & 13 \\
\hline $\begin{array}{l}\text { Rheumatold arthritss. } \\
\text { Rheumatoid arthritis. }\end{array}$ & 0.26 & 0.87 & $106 / 74$ & $90 / 74$ & 8 \\
\hline Chronic & & & & & \\
\hline pyelonephritis. & 0.24 & 0.89 & $186 / 92$ & $142 / 98$ & 21 \\
\hline $\begin{array}{l}\text { Chronic } \\
\text { pyelonephritis. . }\end{array}$ & 0.29 & 1.00 & $140 / 82$ & $128 / 64$ & 15 \\
\hline Tuberculous nephritis & 0.24 & 0.76 & $128 / 98$ & $108 / 70$ & 24 \\
\hline Chronic salpingitis... & 0.23 & 0.81 & $104 / 50$ & $66 / 32$ & 28 \\
\hline
\end{tabular}

In the cases of clubbed fingers secondary to various pulmonary diseases, the blood flows were usually above the upper normal limit, although in a few cases they fell within the normal range. The brachial-digital arterial pressure gradients in the cases of simple clubbing secondary to pulmonary disease were generally less than normal because of elevated digital arterial pressures. In the three cases of hypertrophic osteoarthropathy, the blood flows were within normal limits and the pressure gradients only slightly or moderately less than normal. In one of the cases of lung abscess, the blood flow before operation was above normal and the brachial-digital arterial pressure gradient less than normal because of elevated digital arterial pressure. After incision and drainage there was a partial recession of the clubbing. The blood flow decreased to within normal limits and the digital arterial pressure was lower.

In the two cases of congenital heart disease with cyanosis, the blood flows were high normal in one and above normal in the other. The pressure gradients were less than normal in both. In five of the cases of subacute bacterial endocarditis, the 
TABLE II B

Clubbed fingers

\begin{tabular}{|c|c|c|c|c|c|}
\hline Diagnosis & $\begin{array}{l}\text { Blood } \\
\text { flow }\end{array}$ & $\begin{array}{l}\text { Blood } \\
\text { flow }\end{array}$ & $\begin{array}{l}\text { Brachial } \\
\text { arterial } \\
\text { pressure }\end{array}$ & $\begin{array}{l}\text { Digital } \\
\text { arterial } \\
\text { pressure }\end{array}$ & $\begin{array}{l}\text { Arith- } \\
\text { metic } \\
\text { mean } \\
\text { gradi- } \\
\text { ent }\end{array}$ \\
\hline & $\begin{array}{c}c c . \\
\text { per } \\
\text { sq. cm. } \\
\text { per } \\
\text { minute }\end{array}$ & $\begin{array}{c}c c . \\
\text { per } \\
c c . \\
\text { per } \\
\text { minute }\end{array}$ & $\underset{\mathrm{Hg}}{\mathrm{mm}}$ & $\underset{H g}{m m}$ & $\underset{H g}{m m}$ \\
\hline Bronchiectasis . & 0.32 & 0.93 & $104 / 74$ & $104 / 58$ & 8 \\
\hline Bronchiectasis. & 0.37 & 0.96 & $136 / 92$ & $128 / 94$ & 3 \\
\hline Bronchiectasis. & 0.32 & 0.88 & $128 / 90$ & $122 / 74$ & 11 \\
\hline Bronchiectasis. & 0.34 & 0.85 & $142 / 90$ & $126 / 80$ & 13 \\
\hline Bronchiectasis . & 0.32 & 0.79 & $136 / 90$ & $124 / 76$ & 13 \\
\hline Bronchiectasis . & 0.30 & 0.85 & $124 / 84$ & $120 / 70$ & 9 \\
\hline Bronchiectasis . & 0.37 & 1.10 & $136 / 70$ & $134 / ?$ & \\
\hline Bronchiectasis. & 0.34 & 0.94 & $112 / 74$ & $106 / 65$ & 7 \\
\hline Lung abscess. . & 0.34 & 0.93 & $125 / 74$ & $116 / 66$ & 9 \\
\hline $\begin{array}{l}\text { Lung abscess . . . . . } \\
\text { Lung abscess . . . }\end{array}$ & 0.24 & 0.74 & $126 / 98$ & $102 / 82$ & 20 \\
\hline $\begin{array}{l}\text { (Pre-operative) } \ldots . . . \\
\text { (Post-operative) } . . .\end{array}$ & $\begin{array}{l}0.32 \\
0.27\end{array}$ & $\begin{array}{l}0.96 \\
0.88\end{array}$ & $\begin{array}{l}132 / 82 \\
112 / 75\end{array}$ & $\begin{array}{r}110 / 80 \\
90 / 68\end{array}$ & $\begin{array}{l}12 \\
15\end{array}$ \\
\hline Empyema........... & 0.29 & 0.77 & $138 / 80$ & $124 / 72$ & 11 \\
\hline $\begin{array}{l}\text { Pulmonary } \\
\text { tuberculosis. }\end{array}$ & 0.31 & & $112 / 80$ & $108 / 74$ & \\
\hline Pulmonary neoplasm. & $\begin{array}{l}0.51 \\
0.26\end{array}$ & $\begin{array}{l}0.80 \\
0.98\end{array}$ & $124 / 78$ & $128 / 72$ & 5 \\
\hline Congenital & & & & & \\
\hline $\begin{array}{l}\text { heart dise } \\
\text { Congenital }\end{array}$ & 0.29 & 0.88 & $112 / 94$ & $108 / 75$ & 11 \\
\hline $\begin{array}{l}\text { heart disease.. } \\
\text { Subacute bacteria }\end{array}$ & 0.31 & 0.99 & $102 / 88$ & $92 / 66$ & 16 \\
\hline endocarditis.: & 0.49 & 1.59 & $130 / ?$ & $128 / ?$ & \\
\hline subacute bacterial & 0.32 & 0.88 & $110 / 55$ & $105 / 55$ & 3 \\
\hline $\begin{array}{l}\text { Subacute bacterial } \\
\text { endocarditis . : }\end{array}$ & 0.34 & 0.92 & $90 / 75$ & $84 / 74$ & 4 \\
\hline $\begin{array}{l}\text { Subacute bacterial } \\
\text { endocarditis. . . }\end{array}$ & 0.33 & 0.78 & $124 / 75$ & $110 / 66$ & 12 \\
\hline $\begin{array}{l}\text { Subacute bacterial } \\
\text { endocarditis . ... }\end{array}$ & 0.31 & 0.88 & $102 / 65$ & $86 / 62$ & 9 \\
\hline $\begin{array}{l}\text { Subacute bacterial } \\
\text { endocarditis . . . }\end{array}$ & 0.29 & 0.91 & $122 / 74$ & $96 / 64$ & 16 \\
\hline $\begin{array}{l}\text { Subacute bacterial } \\
\text { endocarditis.... }\end{array}$ & 0.29 & 0.93 & $104 / 72$ & $102 / ?$ & \\
\hline Ulcerative colitis. . & 0.27 & 0.68 & $96 / 60$ & $94 / ?$ & \\
\hline Ulcerative colitis. & 0.32 & 1.28 & $120 / 86$ & $118 / 84$ & 3 \\
\hline Ulcerative colitis. & 0.30 & 0.92 & $114 / 80$ & $110 / 74$ & 5 \\
\hline $\begin{array}{l}\text { Chronic dysentery } \\
\text { Regional ileitis.... }\end{array}$ & $\begin{array}{l}0.24 \\
0.32\end{array}$ & $\begin{array}{l}0.70 \\
1.12\end{array}$ & $\begin{array}{l}110 / 85 \\
102 / 64\end{array}$ & $\begin{array}{r}98 / 82 \\
102 / 60\end{array}$ & $\begin{array}{l}7 \\
2\end{array}$ \\
\hline Sprue......... & 0.34 & 1.36 & $138 / 102$ & $116 / ?$ & \\
\hline $\begin{array}{l}\text { Sprue.. } \\
\text { Osteoar }\end{array}$ & 0.21 & 0.58 & $84 / 56$ & $76 / ?$ & \\
\hline Osteoarthropathy & 0.25 & 0.66 & $124 / 68$ & $95 / 65$ & 16 \\
\hline $\begin{array}{l}\text { Osteoarthropathy (Pul- } \\
\text { monary neoplasm)... }\end{array}$ & 0.29 & 0.72 & $132 / 85$ & $126 / ?$ & \\
\hline $\begin{array}{l}\text { Osteoarthropathy (Pul- } \\
\text { monary neoplasm)... }\end{array}$ & 0.23 & 0.67 & $92 / 66$ & $82 / ?$ & \\
\hline $\begin{array}{l}\text { Hereditary clubbing . . } \\
\text { Hereditary clubbing }\end{array}$ & 0.27 & 0.91 & $145 / 95$ & $125 / 84$ & 16 \\
\hline $\begin{array}{l}\text { (Clubbed finger).. } \\
\text { (Normal finger).. }\end{array}$ & $\begin{array}{l}0.22 \\
0.22\end{array}$ & $\begin{array}{l}0.57 \\
0.61\end{array}$ & $\begin{array}{l}126 / 78 \\
126 / 78\end{array}$ & $\begin{array}{l}104 / 58 \\
108 / 64\end{array}$ & $\begin{array}{l}21 \\
16\end{array}$ \\
\hline
\end{tabular}

blood flows were also above the normal range and the pressure gradients smaller than normal. In the other two cases, the blood flows were high normal and the pressure gradients slightly less than those observed in normal subjects.

The blood flows were also above normal and the pressure gradients less than normal in two of the three cases of ulcerative colitis, in one of the two cases of sprue and in the case of regional ileitis. In the other case of ulcerative colitis, in the other case of sprue and in the case of chronic bacillary dysentery the blood flows were within the normal range, although the pressure gradients were somewhat smaller than normal.

In' the two cases of hereditary clubbing, both the blood flows and pressure gradients were within normal limits. In one of these cases, only three fingers of each hand were clubbed. There was no essential difference, however, between the blood flow per sq. cm. or digital arterial pressure of a clubbed finger and that of a normal finger of the same hand.

In normal subjects, the average blood flow per sq. $\mathrm{cm}$. per minute was $0.253 \mathrm{cc} . \pm$ a standard deviation of $0.026 \mathrm{cc}$. The average blood flow per cc. per minute was $0.72 \mathrm{cc} \pm$ a standard deviation of $0.122 \mathrm{cc}$. The average arithmetic mean gradient was $23.1 \mathrm{~mm}$. $\mathrm{Hg} \pm$ a standard deviation of $7.1 \mathrm{~mm}$. In the cases of clubbing, hereditary clubbing and hypertrophic osteoarthropathy excepted, the average blood flow per sq. $\mathrm{cm}$. per minute was $0.314 \mathrm{cc}$. \pm a standard deviation of $0.049 \mathrm{cc}$. The average blood flow per cc. per minute was $0.93 \mathrm{cc}$. \pm a standard deviation of $0.199 \mathrm{cc}$. The average arithmetic mean gradient was $8.8 \mathrm{~mm}$. $\mathrm{Hg} \pm \mathrm{a}$ standard deviation of $4.9 \mathrm{~mm}$.

\section{SUMMARY AND CONCLUSIONS}

1. The Stewart method for measuring blood flow has been shown to be accurate when applied to the finger tip.

2. The normal range of variation of blood flow and brachial-digital pressure gradient, after release of sympathetic tone, has been determined.

3. In essential hypertension, aplastic anemia, hyperthyroidism, acromegaly and diverse chronic infections, all without clubbing, the blood flows and pressure gradients were within the normal range.

4. In all the varieties of simple clubbing studied, except hereditary clubbing, the blood flows per unit surface or volume of finger tip were abnormally high. These excessive flows were caused, in part at least, by elevated digital arterial pressures. Since the brachial arterial pressures were 
unchanged, the brachial-digital gradients were reduced. After incision and drainage of a lung abscess, the previously increased blood flow and digital arterial pressure returned to normal with recession of the clubbing. It is therefore apparent that abnormally high blood flow and digital arterial pressure after release of sympathetic tone are peculiar to ordinary clubbing and integral forces in its development. In hereditary clubbing, the normal blood flow per unit of tissue and the normal pressure values found indicate that the mechanism of clubbing here is different from that which operates in the ordinary cases.

5. In hypertrophic osteoarthropathy, the blood flow per unit of tissue and the digital arterial pressure were within normal limits. Since the mean digital arterial pressure can never be higher than the mean brachial, the increase in digital arterial pressure, and hence in digital blood flow in simple clubbing without bone changes, is limited. As the circulatory derangement associated with clubbing advances, therefore, it is possible that there is a recession or at least a stabilization of the phenomenon in the finger tips and that the process of increased blood flow and hypertrophy is taken over by the bones.
This opportunity is taken to acknowledge the cooperation of Drs. George Baehr, B. S. Oppenheimer, A. Hyman and Harold Neuhof from whose services these cases were studied, of Dr. William Bierman in whose department the procedures were carried out, and of $\mathrm{Dr}$. A. Kolin who made the needle thermocouple. The technical assistance of Miss G. Urquhart and Miss C. Corn is also gratefully acknowledged.

\section{BIBLIOGRAPHY}

1. Mendlowitz, M., Some observations on clubbed fingers. Clin. Sc., 1938, 3, 387.

2. Stewart, G. N., Studies on the circulation in man. I. Measurement of the blood flow in the hands. Heart, 1911, 3, 33. II. The effect of reflex vasomotor excitation on the blood flow in the hand, ibid, 76.

3. Harris, K. E., and Marvin, H. M., A note on the temperature of venous blood and its use in estimating rate of blood flow to the hand. Heart, 1927, 14, 49.

4. Pickering, G. W., The peripheral resistance in persistent arterial hypertension. Clin. Sc., 1936, 2, 209.

5. Wilkins, R. W., Doupe, J., and Newman, H. W., The rate of blood flow in normal fingers. Clin. Sc., 1938, 3, 403.

6. Gaertner, G., Uber einen neuen Blutdruckmesser (Tonometer). Wien. klin. Wchnschr., 1899, 12, 696. 